\title{
Analysis of Topic Development in Guided Writing in Terms of Theme and Rheme
}

\author{
Yoko Suganuma Oi
}

\begin{abstract}
The topic development in guided writing was analyzed in terms of theme and rheme based on teacher assessment. 82 Japanese high school students, one native English teacher and one Japanese English teacher participated in the study. Students were asked to write about 150 words on the guided writing topic and then both students and teachers assessed students' English composition using the same assessment sheet. The result showed that the frequency of the progression of theme and rheme was not related to the scores. Half of the students used all of the types of progression in their compositions. Preferably the number of T-units was connected to the scores. It was also observed that teaching the progression of theme and rheme could be helpful for students to develop a topic and learn how to make their written production coherent.
\end{abstract}

Index Terms - Guided writing, theme, rheme.

\section{INTRODUCTION}

I have analyzed the relationship between teacher assessment and student self-assessment of Topic development in guided writing among high school students in terms of discourse markers, structure of organization, and coherence [1]. Whereas the topic identification of "theme" and "rheme" has not been analyzed in my previous study, the progression of "theme" and "rheme" is surveyed in the present study. Since the progression of "theme" and "rheme" is one of the factors which comprises coherence, I would also like to find the educational implification to improve high school students' written production, especially their topic development. For the topic development of high school students' written production has not been discussed well, because feedback on form has been the main point of attention in the classroom, especially in Japanese high schools. Therefore it is meaningful to analyze the progression of the "theme" and "rheme" to find the way to improve students' written production.

\section{PREVIOUS STUdIES}

\section{A. Coherence Defined}

When we analyze topic development, cohesion and coherence are very important aspects. Cohesion and coherence are different, but they are both very interactive. So reference [2] mentions that cohesion and coherence interact to a great degree, but a cohesive text may be only minimally

Manuscript received September 4, 2014; revised February 12, 2015.

Yoko Suganuma Oi is with Graduate School of Education, Waseda University, 1-6-1, Nishi-Waseda, Shinjuku-ku, Tokyo, CO169-8050, Japan (e-mail: yokosuganuma@suou.waseda.jp). coherent. Reference [3] indicates that using cohesive ties successfully is apparently not easy. Both good and poor writers may use the same kinds of cohesive ties, but they use them differently. According to [4], we can say that the coherent writing should be reader-friendly. It helps the readers organize, interpret, and evaluate information given, making the writing more accessible to the readers. So coherence in written production means that all the ideas in a text stick together and flow smoothly from one sentence to the next sentence.

Reference [5] categorizes coherence into two types: interactional coherence and propositional coherence. Interactional coherence occurs when succeeding speech acts in discourse are implicitly connected, and such coherence is noticeable in informal spoken language. On the other hand, propositional coherence concerns the implicit links made by the ideational content of the discourse and is predominant in more formal settings and in written language. The present study discusses written production, so propositional coherence is focused on more.

Thus coherence is an important component to evaluate written production, but its subjectivity has also been discussed. For instance, [6] mentions that coherence is subjective and judgments concerning it may vary from reader to reader. On the other hand, [7] insisted that an "overwhelming consensus" of opinion concerning the level of naturally-occurring discourse can be achieved, even though coherence is subjective.

Concerning a method of assessing coherence of written production, [7] presents the applicability of topic-based teachers' marks for coherence. Reference [7] shows that the number of moves between key concepts per ten T-units correlates most closely with the teachers' marks. The researcher also analyzes the coherence of written production in terms of discourse topic. The replies of the proposal of English composition are linked together using lexical networks. However, coherence from the viewpoint of theme and rheme has not been analyzed yet. The analysis of theme and rheme leads to the more specific or precise analysis of coherence.

\section{B. Theme and Rheme Defined}

According to [8], a theme is "what the sentence is about" and a rheme is "what is said about the theme". Reference [9] mentions that the importance of theme-rheme analysis concerns how consecutive sentences are related. Reference [10] explains:

A clause consists of a Theme accompanied by a Rheme; and the structure is expressed by the order---whatever is chosen as the Theme is put first. The message thus unfolds 
from thematic prominence---the part that the speaker has chosen to highlight as the starting point for the addressee---to thematic non-prominence (p. 89)

For instance, the structure of Theme and Rheme becomes as Table I.

TABLE I: THE STRUCTURE OF THEME AND RHEME (HALLIDAY, 2014)

\begin{tabular}{|c|c|c|}
\hline & Theme & Rheme \\
\hline 1 & The duke & has given my aunt that teapot \\
\hline 2 & What I want & is a proper cup of coffee \\
\hline 3 & Merrily & we roll along \\
\hline 4 & On Saturday & I lost my wife \\
\hline 5 & This & they should refuse \\
\hline 6 & Who & wants a glass of white wine? \\
\hline 7 & and how long & is she there for? \\
\hline 8 & Shall I & make some toast? \\
\hline 9 & on the right & is it? \\
\hline 10 & $\begin{array}{l}\text { After all, except for } \\
\text { music, }\end{array}$ & what did they have in common? \\
\hline 11 & I didn't know & I was out. \\
\hline 12 & to what extent & $\begin{array}{l}\text { is the Snow Leopard a shaped } \\
\text { creation? }\end{array}$ \\
\hline 13 & in which & it took place \\
\hline 14 & (I asked) why & no one was around \\
\hline 15 & with (all the doors) & being locked \\
\hline 16 & while & no blaming them \\
\hline
\end{tabular}

Theme is the message which the writer send to the reader. The writer chooses the Theme as his or her point of departure to guide the reader in developing an interpretation of the message. Rheme is the reminder of the message. Theme is accompanied by Rheme. Theme always starts from the beginning of the clause. Therefore Theme could be recognized as a topic. Rheme could be taken as a comment.

Reference [11] presents three types of progressions of theme and rheme: 1) sequential progression, 2) parallel progression, and 3) extended parallel progression. Sequential progression means that the rheme of one sentence becomes the theme of the succeeding sentence such as $\langle a, b\rangle,\langle b, c\rangle$, $<\mathrm{c}, \mathrm{d}\rangle$. Parallel progression means that the theme of one sentence can be repeated as the theme of the next sentence like $\langle\mathrm{a}, \mathrm{b}\rangle,\langle\mathrm{a}, \mathrm{c}\rangle,\langle\mathrm{a}, \mathrm{d}\rangle$. Extended parallel progression occurs when a previous theme, which may have been interpreted is taken up again, as in the sequence, $\langle a, b\rangle,\langle\mathrm{b}, \mathrm{c}\rangle,\langle\mathrm{c}, \mathrm{d}\rangle,\langle\mathrm{a}$, e>. Using these types of progressions, English compositions of high school students are analyzed, because it enables to analyze coherence more specifically compared to the analysis of discourse topic.

\section{RESEARCH QUESTIONS}

The purpose of the present study is to investigate and answer the following two research questions:

1. What types of progression of "theme" and "rheme" do Japanese high school students employ in their English compositions?

2. Based on the results what instruction is needed to improve English writing?

\section{DATA COLLECTION}

\section{A. Participants}

The data for the analysis came from the written production of 82 Japanese high school students. Their ages ranged from 16 to 18 years old. One American English teacher and one Japanese English teacher also participated in the study. Before the research, every student received the instructions of writing patterns and comments about their previous English compositions. Teachers gave a lecture on Topic Development. Students were asked to write an essay on the guided writing topic, "A foreign visitor has only one day to spend in your country. Where should this visitor go on that day? Why? Use specific reasons and details to support your choice" about 150 words in 30 minutes. Students were not informed of the topic before writing. Students were not allowed to use a dictionary during writing. Students assessed their written production after writing, using the same assessment sheet as teachers. The assessment sheet consisted of five components: "Introduction", "Body", "Conclusion", "Discourse Markers", "Coherence", and "General Evaluation". Each component of Topic Development is composed of 3 scores, and "General Evaluation" is 5 point. So the full mark of this assessment sheet is 20 points. Table II presents the scores of teacher assessment about Topic Development.

TABLE II: TEACHER ASSESSMENT ABOUT TOPIC DEVELOPMENT

\begin{tabular}{|c|c|c|c|c|}
\hline \hline $\mathbf{N}$ & MAX & MIN & MEAN & SD \\
\hline 82 & 20 & 2 & 13.20 & 4.02 \\
\hline \hline
\end{tabular}

Table III shows three divisions of the students. It depends on the results of teachers' rating: high scored group (16-20 points), middle scored group (15-11 points), and low scored group (10-2 points).

TABLE III: TEACHER ASSESSMENT ABOUT TOPIC DEVELOPMENT

\begin{tabular}{|c|c|c|c|}
\hline \multicolumn{2}{|c|}{ TABLE III: TEACHER ASSESSMENT ABOUT TOPIC DEVELOPMENT } \\
\hline \hline & $\begin{array}{c}\text { High scored } \\
\text { group }\end{array}$ & $\begin{array}{c}\text { Middle scored } \\
\text { group }\end{array}$ & $\begin{array}{c}\text { Low scored } \\
\text { group }\end{array}$ \\
\hline Scores & $20-16$ points & $15-11$ & $10-2$ \\
\hline $\begin{array}{c}\text { NO of } \\
\text { students }\end{array}$ & 27 & 26 & 29 \\
\hline \hline
\end{tabular}




\section{B. Inter-rater Reliability between Two Teachers'} Assessment

The inter-rater reliability between the assessments by two teachers was calculated before the two teachers' total sum. It was found that there was a high correlation between the assessments by two teachers. To confirm the reliability of two teachers' assessment, the inter-rater reliability between the assessments by six teachers was also calculated. It was found that there was a high correlation between the assessments of teachers except one teacher. The researcher chose two teachers' assessment, because they were class teachers. The data was analyzed based on the results of two teachers, NET1 and JET1. Table IV shows the inter-rater reliability between two teachers' assessments. It indicates the high inter-rater reliability.

TABLE IV: INTER-RATER RELIABILITY BETWEEN TWO TEACHERS' ASSESSMENTS

\begin{tabular}{|l|c|c|c|}
\hline \hline Components & Introduction & Body & Conclusion \\
\hline $\begin{array}{l}\text { Kendall's tau } \\
\text { coefficient }\end{array}$ & $.970^{* *}$ & $.939^{* *}$ & $.867^{* *}$ \\
\hline \hline
\end{tabular}

\begin{tabular}{|c|c|c|}
\hline \hline $\begin{array}{c}\text { Discourse } \\
\text { Markers }\end{array}$ & Coherence & Total Score \\
\hline \multirow{1}{*}{$* p<05$} & $.985^{* * *}$ & $.922^{* *}$ \\
\cline { 2 - 4 } & $* * p<.01$ &
\end{tabular}

\section{RESULTS}

Table V presents the distribution of teacher assessment's scores of coherence. The compositions of high scored students are evaluated higher by teachers. On the other hand, low scored students' compositions are evaluated lower by teachers. It means that high scored students developed a topic better in their written production than other scored students.

TABLE V: DISTRIBUTION OF TEACHER ASSESSMENT'S SCORES OF COHERENCE

\begin{tabular}{|l|c|c|c|c|}
\hline \hline Groups & $\begin{array}{c}\text { NO of } \\
\text { student } \\
\text { s }\end{array}$ & 3 points & 2 & 1 \\
\hline 82 & 82 & $40 / 82=0.487$ & $33 / 82=0.402$ & $11 / 82=0.13$ \\
students & 27 & $19 / 27=0.703$ & $8 / 27=0.296$ & $0 / 27=0.000$ \\
\hline $\begin{array}{l}\text { High } \\
\text { scored } \\
\text { students }\end{array}$ & 26 & $12 / 26=0.467$ & $11 / 26=0.423$ & $4 / 26=0.153$ \\
\hline $\begin{array}{l}\text { Middle } \\
\text { scored } \\
\text { students }\end{array}$ & 29 & $9 / 29=0.310$ & $14 / 29=0.482$ & $7 / 29=0.241$ \\
\hline $\begin{array}{l}\text { Low } \\
\text { scored } \\
\text { students }\end{array}$ & & & & 4 \\
\hline \hline
\end{tabular}

Table VI presents that about half of the students used the combination of three types of progressions in their English compositions. Parallel and extended parallel progressions were used as the second most frequent. Therefore about half of the students used all of the types of progressions of theme and rheme when they developed a topic. Students have already acquired how to combine the progression of theme and rheme in their written production.

TABLE VI: APPEARANCE OF THEME AND RHEME

\begin{tabular}{|c|c|c|c|}
\hline \hline $\begin{array}{c}\text { Sequential } \\
\text { progression }\end{array}$ & $\begin{array}{c}\text { Parallel } \\
\text { progression }\end{array}$ & $\begin{array}{c}\text { Extended } \\
\text { parallel } \\
\text { progression }\end{array}$ & $\begin{array}{c}\text { Frequency of } \\
\text { appearance }\end{array}$ \\
\hline 0 & 0 & 0 & 45 \\
\hline 0 & 0 & 0 & 9 \\
\hline 0 & 0 & 0 & 9 \\
\hline 0 & & & 1 \\
\hline & & & 2 \\
\hline
\end{tabular}

Table VII presents the average frequency of three types of progressions of each group. High scored students' group showed the highest frequency of "parallel progression", "extended parallel progression", and the sum of three ways of progressions. Middle scored students' group showed the highest frequency of "sequential progression". So the frequency of theme and rheme progression was not related to the teacher's assessment. On the other hand, the number of T-units was related to the score of Topic development. High scored students showed the highest number of T-units. However, the ratio of theme and rheme per T-unit was not proportional to the level of students.

TABLE VII: THE AVERAGE OF FREQUENCY OF THREE TYPES OF PROGRESSION AND T-UNIT

\begin{tabular}{|l|c|c|c|c|}
\hline \hline & Overall & $\begin{array}{c}\text { High } \\
\text { scored } \\
\text { students }\end{array}$ & $\begin{array}{c}\text { Middle } \\
\text { scored } \\
\text { students }\end{array}$ & $\begin{array}{c}\text { Low } \\
\text { scored } \\
\text { students }\end{array}$ \\
\hline $\begin{array}{l}\text { Frequency of } \\
\text { sequential } \\
\text { progression }\end{array}$ & 3.64 & 3.37 & 4.05 & 3.5 \\
\hline $\begin{array}{l}\text { Frequency of } \\
\text { Parallel } \\
\text { progression }\end{array}$ & 6.29 & 6.65 & 6 & 6.21 \\
\hline $\begin{array}{l}\text { Extended } \\
\text { parallel } \\
\text { progression }\end{array}$ & 3.68 & 3.82 & 3.18 & 4 \\
\hline $\begin{array}{l}\text { Sum of 3 types } \\
\text { of progression }\end{array}$ & 11.05 & 11.30 & 10.88 & 10.97 \\
\hline $\begin{array}{l}\text { NO of T-units } \\
\text { Natio of theme } \\
\text { \&rheme per } \\
\text { T-unit }\end{array}$ & 0.556 & 0.549 & 0.541 & 0.579 \\
\hline \hline
\end{tabular}




\section{DISCUSSION}

\section{A. Research Question 1}

About half of the students used three types of progression of theme and rheme, so half of the students could use all of the types of progressions. It was also found that every group used parallel progression most frequently. For it was assumed that students tried to be consistent with the topic of the composition and then it was easier for them to develop their ideas on the topic.

Though high scored students' group showed the highest frequency of total frequency of three progressions, it cannot be said that the frequency of theme and rheme is a predictor variable for teacher's score of coherence. The researcher assumes that discourse topic might be more predictable of teacher assessment.

\section{B. Research Question 2}

Coherence is made up of each sentence in a text, so it is effective to teach how to link with themes, sentence by sentence. It was observed that teaching the progression of theme and rheme prevented students from "jumps" of discontinuous discourse, because the continuation of theme and rheme produces the development of topic in written production. Japanese high school students are supposed to learn sentence structure such as "subject", "verb", and "object" in English grammar class. Compared to the study of sentence structure, the structure of theme and rheme encourage students to produce English sentences more easily, because students could be more conscious of "topic" which they want to write as writers. Moreover, the study of progression of theme and rheme helps students to make a paragraph, because it would be a guide to develop a "topic". Therefore teaching the progression of theme and rheme is meaningful for students to improve English learning.

\section{CONCLUSION}

The present study focused on the progression of theme and rheme. Teaching the progression of theme and rheme would help students to make a sentence and finally develop a topic in their whole written production, but the ratio of theme and rheme did not prove that it could be a predictor of teacher assessment. The present study did not examine the accuracy of language use. So there is a possibility that teacher assessment is related to the accuracy, because the frequency of progression of theme and rheme was not proportional to teacher assessment. As a further study, the relationship between coherence and accuracy of language use should be investigated.

\section{ACKNOWLEDGMENT}

I wish to acknowledge my deep appreciation to the following people for their ongoing encouragement and advice. I would like to express my utmost appreciation to my supervisor, Professor Michiko Nakano for her insightful advice. I am also grateful to all the teachers and students who participated in the study. Finally, I appreciate my husband's constant encouragement and support.

\section{REFERENCES}

[1] S. Y. Oi, "Self-assessment of topic development in written production among high school students," Journal of Pan-Pacific Association of Applied Linguistics, vol. 18, no. 1, pp. 145-169, 2014.

[2] S. P. Witte and L. Faigley, "Coherence, cohesion, and writing quality," College Composition and Communication, vol. 32, pp. 189-204, 1981

[3] C. G. Hartnett, "Static and dynamic cohesion: signals of thinking in writing," in Functional Approaches to Writing, B. Couture, Ed. London: Pinter, 1986, pp. 142-151

[4] I. Lee, "Enhancing ESL students' awareness of coherence-creating mechanisms in writing," TESL Canada Journal, vol. 15, no. 2, pp 36-49, 1998.

[5] M. Stubbs, Discourse Analysis: The Sociolinguistic Analysis of Natural Language, Oxford: Blackwell, 1983.

[6] M. Hoey, Patterns of Lexis in Text, Oxford: Oxford University Press, 1991.

[7] W. Todd, P. Thienpermpool, and S. Keyurvong, "Measuring the coherence of writing using topic-based analysis," Assessing Writing, vol. 9, pp. 85-104, 2004.

[8] W. Todd, "Topic-based analysis of classroom discourse," System 26 pp. 303-318, 1998.

[9] P. H. Fries, "On the stats of theme in English: Arguments from discourse," in Micro and Macro Connexity in Texts Petofi, J. S. E. Sozer, Ed. Hamburg: Helmet BuskeVerlag, 1983.

[10] M. A. K. Halliday, Functional Grammar, Routledge, 2014.

[11] L. Lautamatti, "Observations on the development of the topic in simplified discourse," in Writing Across Languages: Analysis of L2 Text, U. Connor and R. B. Kaplan, Eds. MA: Addison-Wesley, Reading, 1978, pp. 87-113.

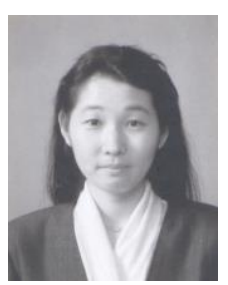

Yoko SuganumaOi was born in Japan. She received her master degree of arts, in Columbia University in 2001; master degree of education, in Waseda University in 2012; she is now a Ph. D candidate of Waseda University.

Her latest study work is self-assessment of topic development in written production among high schoo students in Journal of Pan-Pacific Association of Applied Linguistics of 2014. She is interested in self-assessment and peer assessment.

Ms. Oi belongs to Pan-Pacific Association of Applied Linguistics, The Japan Association for Language Teaching, and The English Language and Literature Society of Waseda University. 